\title{
Physiological Parameters Related To Anxiety In Dental Surgery
}

\author{
Marlussy Soares - Maffei ${ }^{1}$, Kaohana Thaís da Silva $^{1}$,Dejoane Muraro Pommer ${ }^{1}$ \\ Vanessa Piva ${ }^{1}$,Marla Katielly Barbosa de Oliveira Thomaz ${ }^{1}$,Luiz César Lopes ${ }^{1}$ \\ Daniela de Cássia Faglioni Boleta-Ceranto ${ }^{1}$ \\ ${ }^{I}$ (Department of Odontology, Universidade Paranaense, Brasil
}

\begin{abstract}
The anxiety is an emotional state that cannot be controlled by the consciousness, thus it causes many symptoms which can interfere on dental care. This work reviews the anxiety concepts and evaluates the physiological parameters related to anxiety in 55 patients subjected to surgical procedure on the Surgery Course of the third molar at Unipar's clinic of Cascavel, through a questionnaire, measurement of arterial pressure and heart rate before and after the surgical procedure. Onwards the ANOVA tests and t-student test for data analysis, it was determined that the female patients seemed more anxious than the male gender. On the post-operative was found values with higher peaks of arterial pressure, as well it was observed a statistically difference in both genders in situations which some complication happened.
\end{abstract}

Keywords: Anxiety. Odontological treatment. Arterial pressure. Heart rate.

\section{Introduction}

The anxiety is an emotional state with psychological and physiological components. It is phenomenon which can be characterized by subjective feelings of tension, apprehension, nervousness and concerns; which are experienced by an individual in a private moment ${ }^{1}$. It does not control the anxiety with consciousness ${ }^{2}$. Thereby, people don't have capacity of interrupting it, aggravating a psychological suffering caused by pain. A study in animals using an orofacial pain model showed that both superficial pain and deep pain at the region are capable of raising the anxiety level ${ }^{3}$. The anxiety is not a disease or a disease symptom, but an emotional answer against a real or potential danger ${ }^{4}$

The anxiety triggers signs and symptoms on patients. Between the physic symptoms the sudoresis, fatigue, shortness of breath, dryness of the mouth, dizziness, nausea, diarrhea, heat waves and chills, frequent urination, concentration difficulty, nervousness, insomnia, irritability and swallowing difficulty ${ }^{5}$. Between the physiological behavior alterations, the raise of the respiratory rate (tachypnea) and heart rate (tachycardia), raise of the muscular tension, elevation of the arterial pressure, paleness and shivering ${ }^{4}$.

When the anxiety feeling or fear occurs front of the perspective or in relation to Odontological treatment, it has been called the dental anxiety, which intensity varies from patient to patient or even though at the same patient according to the kind of procedure ${ }^{6}$. Some patients unleash the anxiety and the fear of seeing the needle used for the anesthesia, the dental tools on the table and when listening the sound of the dental handpieces (such as the drill). In the dental clinic, the anxiety reflects, in general, feelings determined by previous experiences of pain and suffering, associated to dental problems and its specific attending ${ }^{7}$. One of the main elements which seem to interfere on the behavior of most part of the individuals who look for dental care is the belief that they will be subjected to some sort of discomfort during the treatment ${ }^{8}$. The lack of knowledge of the surgery procedures to be performed determined the significant raise of the anxiety levels. The anxiety levels of the patients who were aware of the procedure details turned up to be lower'

The extraction of a third molar is considered an invasive surgical procedure and potentially adverse to the dental patient for involving some potential complications during and after the intervention, such as: pain, bleeding, lockjaw, swelling, infection, alveolar osteitis, nerve lesion and damage to the surrounding tooth ${ }^{10}$. The surgery of a third molar involves a needle penetration, distancing tissues by levers and removal of the tooth by forceps. Therefore, it is possible to comprehend that it involves a variety of behavior manifestations, such as the strangeness or lack of knowledge of the surgical situation, uncertain related to the possible benefits or ravages, perception of impotence, in other words, the surgical situation favors the occurrence of anxiety indicators ${ }^{11}$.

One of the most evident effects on the physiological balance modification on the patient under pain, anxiety and/or tension is the arterial pressure alteration. Many studies on the literature affirm this arterial pressure variation ${ }^{12}$. Patients with high anxiety traces show an increase on arterial pressure systolic in some dental procedures, suggesting that a raise of arterial pressure can be related to fear or to anxiety ${ }^{13}$. Ferraz et al $(2007)^{14}$ evaluated a variation of arterial pressure and heart rate in pre, intra and post-operative, concluded that there is a meaningful arterial pressure variation during the dental surgical procedure, given that the systolic pressure and heart rate peak occurred on the pre-operative situation, which means, before the anesthesia. This 
fact suggests the influence of the psychological factor on the arterial pressure variation, once the local anesthetic with vasoconstrictor still had not been administrated ${ }^{14}$.

The anxiety to odontological treatment, undoubtedly, constitutes itself in a big obstacle, by making the patient do not look for appropriate assistance at the proper time, mainly by the possibility of feeling pain and suffering ${ }^{15}$. These patients look for this kind of service only when they show clinical signs and/or symptoms such as pain, swelling and fistulas ${ }^{16}$. It turns out to be difficult the administration of the anxiety feeling, which causes an additional difficulty to the dentistry professional ${ }^{17}$. Many times these feelings are undervalued by the professionals, who do not have proper handling, strengthening the fear and the anxiety in future procedures ${ }^{7}$.

The role of the dental surgeon should not stick to the execution of the oral treatment, but include de identification of generator situations of anxiety for the patient and investigation of their possible origins ${ }^{18}$. The patient's emotional reactions reflect in his/her vital signs, which swing in unusual levels. The identification and the control of these physiological indicators promote the treatment success, avoiding emergency situations which can exposure the patient to risk situations; these, sometimes, obligate the professional to abort the procedure. That way, the arterial pressure measurement and the body and pulsation temperature monitoring, by the radial pulse measurement, are part of the analysis which will elucidate the patient's general health ${ }^{19}$.

In Brazil, the anxiety has been poorly investigated. There are a few recent works, and due to the importance of getting greater information about the anxiety degree in surgical procedures, it is why this study turns to be necessary. The anxiety control optimizes the treatment, so, the patient who shows himself/herself calm, becomes more cooperative and feels fewer painful sensations, which confers comfort to him/her and security to the professional, improving the attendance ${ }^{20}$.

The goal of the present study was to analyse the patient's anxiety degree towards the third molar surgery procedure, through the questionnaire and heart rate and arterial pressure evaluation, such as to which moment the greater anxiety peak has occurred, pre or post-operative.

\section{Materials and methods}

The protocol of the study was evaluated and approved for execution by the Ethics Committee of Research in Human Beings (CAAE: 24543613.0.0000.0109). The study was performed with 55 patients on the Surgery Course of third molars of Unipar, at the University of Cascavel.

Before the surgery, it was performed a arterial pressure measurement of the volunteers with 2 appliances: one digital (Panasonic, model EW - BU04) which method of pressure obtainment was the oscillometric and other analogical (sphygmomanometer, brand Welch Allyn, model Tycos and stethoscope brand Littman, model Classic 2) which method was the auscultatory, both properly calibrated. Each device was used by a responsible previously oriented to a standard measurement. Therefore, the vital arterial pressure systolic and diastolic signs with both pressure devices simultaneously, and the heart rate only with the digital appliance. For the arterial pressure verification, the recommended procedures were followed according to the VI Brazilian Hypertension Guidelines ${ }^{21}$. The patient was instructed not to talk during the measurement. The sitting position, legs crossed, feet on the floor, back resting on the chair and relaxed. The arm on the heart height, free from clothes, leaned, with the hand palm facing up and the elbow slightly flexed.

After the arterial pressure values of both measurement appliances been obtained and noted, the volunteers filled a questionnaire containing questions such as: age, gender, visit frequency to the dentist, anxiety and bad experiences in the dental clinic. After, the patients were forwarded to the surgery.

Immediately after the surgical procedure, once more it was performed a arterial pressure and heart rate measurement following the same measurement methods on the pre-surgical stage, and it was also asked to the volunteers if there were, or there were not complications during the procedure.

From the statistic analysis, the ANOVA tests were used and also t-students tests on the Sigma plot program. The graphics were made on Excel 2010 program.

\section{Results}

The sample was constituted by 55 people, 39 females $(70,9 \%)$ and 16 males $(29,1 \%)$. The age average was 26,36 years old, varying from 16 to 50 . The patients were questioned about their anxiety state, and from 55 patients, 37 reported they were anxious, while 18 were not. From 16 men, 8 told they were nervous, which means, 50\% of the sample. Among the 39 women, 29 reported anxiety, representing 74,35\%. This way, it can be observed a high anxiety percentage in the females, showing that women reported, on the present study, they were more anxious than men.

For the heart rate and arterial pressure measurement, 2 appliances were used, an analogical and a digital one. As there was no statistically meaningful difference between both ( $>>0,05)$ of them, for the data analysis, the used values were the ones obtained by the analogical device. 
First evaluating the heart rate before and after the procedure, it was verified that there was no statistically meaningful difference ( $p>0,05)$, such as on the heart rate of female gender $(p>0,05)$, as on the heart rate of male gender $(\mathrm{p}>0,05)$, as it shows in Picture 01

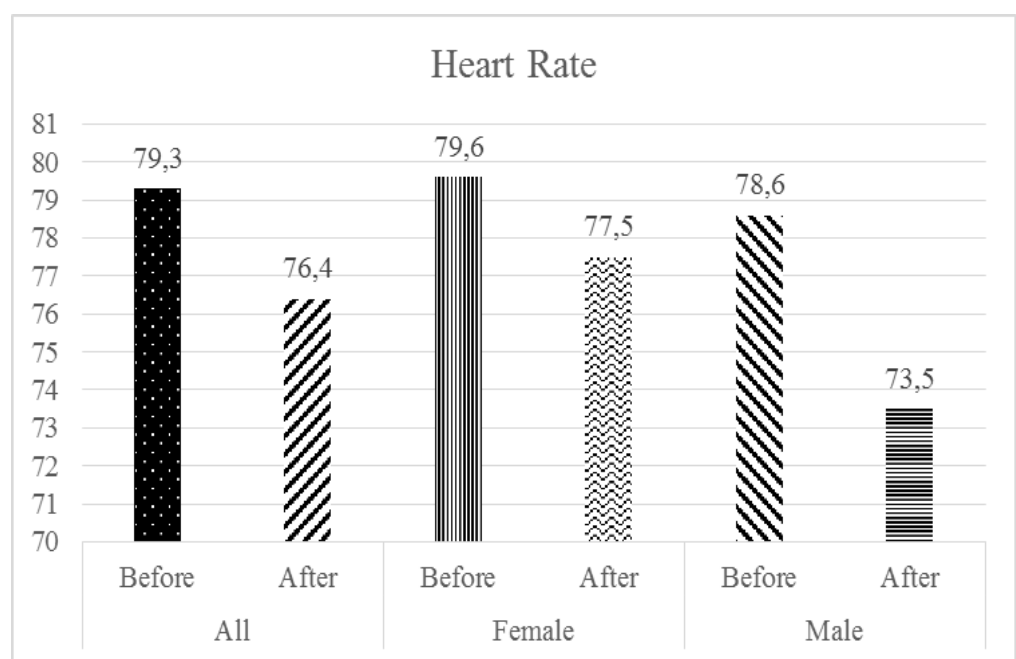

Picture 01 - Demonstrates heart rate (HF) results of volunteers before and after the procedure $p>0,05$ ).

In relation to arterial pressure, initially it was evaluated the PAS variations and after, the arterial pressure diastolic ones. As it is shown in Pictures 2 and 3, it can be noticed that there was a statistically meaningful difference $(\mathrm{p}<0,05)$ in arterial pressure systolic as much as in arterial pressure diastolic, before and after the treatment, being the greater value, in average, after the surgical procedure. On the arterial pressure systolic and arterial pressure diastolic evaluation of the female volunteers it was observed a statistically meaningful difference $(p<0,05)$, showing the greater values on post-surgical; whereas, in relation to the male gender there was no meaningful difference $(p>0,05)$ on arterial pressure systolic or arterial pressure diastolic evaluation.

On the situations were some kind of complication happened, arterial pressure systolic and arterial pressure diastolic were evaluated and it was verified that there was a statistically meaningful difference $(\mathrm{p}<0,05)$, given that the greater values, on average, were found after the surgical procedure, as it is shown in the Pictures 04 and 05 . The arterial pressure systolic values variations, in females as much in males, showed a statistically meaningful difference $(\mathrm{p}<0,05)$, being the post-procedure of a greater value, in average. However, on arterial pressure diastolic, the meaningful difference only occurred in the female gender $(p<0,05)$.

The arterial pressure systolic average of all the volunteers, in the cases that there were no complications during the surgical procedure, there was no statistically meaningful difference $(p>0,05)$. When the volunteers were divided by gender, there was only a meaningful difference on the female gender $(p<0,05)$. The male volunteers did not present statistically meaningful differences of arterial pressure systolic $(p>0,05)$ before and after the procedure, as it is shown on a picture 02 .

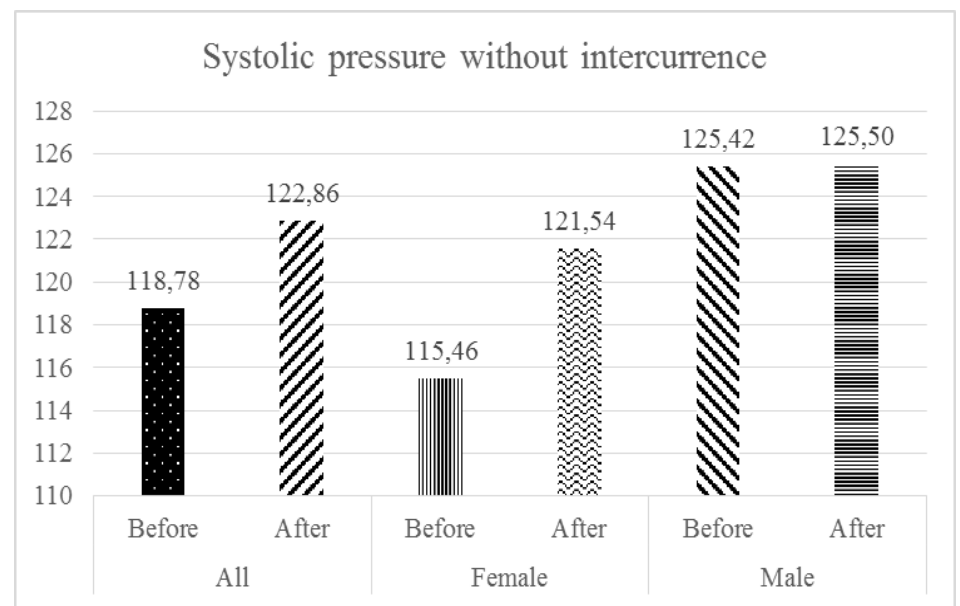

Picture 02 - Mean variation of arterial systolic pressure of all volunteers and separated by gender, before and after the surgical procedure, without intercurrence.al 
Related to the arterial pressure diastolic values, there was no meaningful difference for any gender, as it is shown on picture 03 .

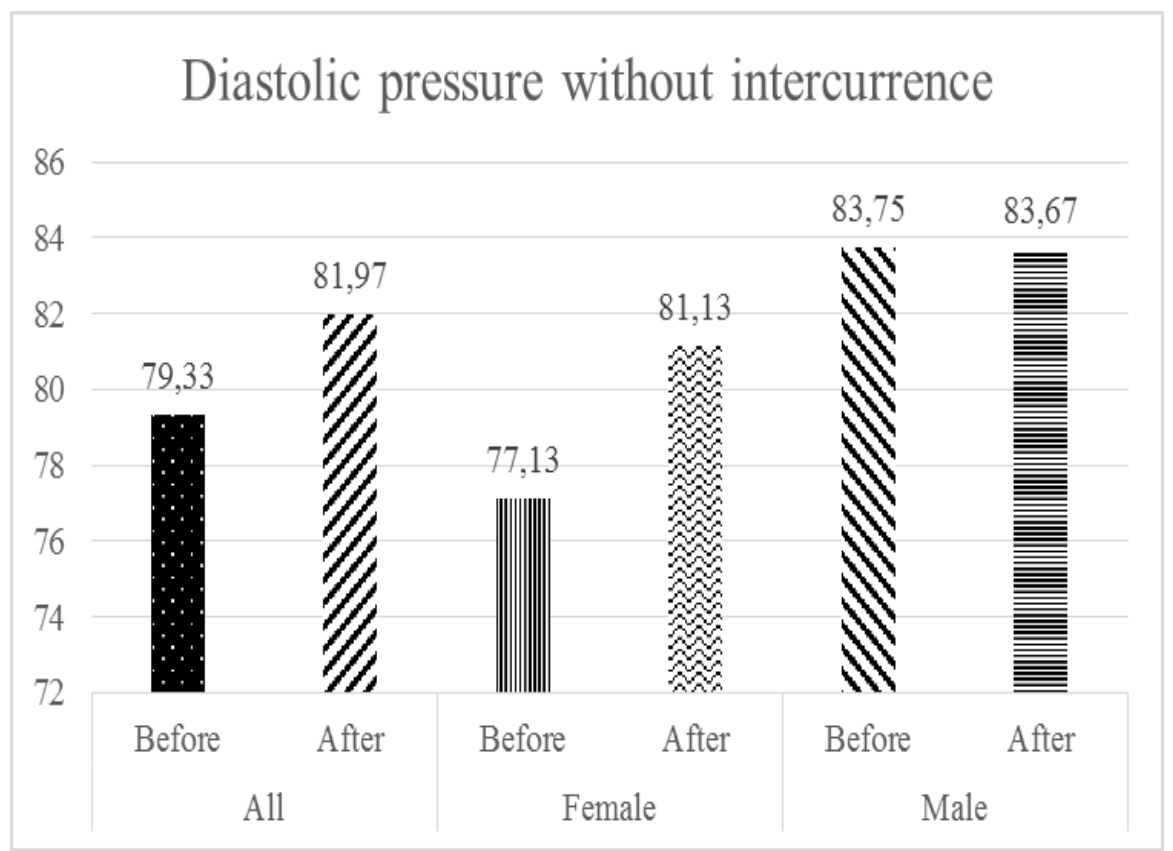

Picture 03 - Mean variation of the DBP of all volunteers and separated by gender, before and after the surgical procedure, without intercurrence.

Assessing the total time of the surgical procedures, on the situations with complications and also on the ones without complications, it was determined that there was no statistically meaningful difference $(p>0,05)$, as it is shown on Picture 04.

\begin{tabular}{|l|c|}
\hline & Mean Surgical Time \\
\hline All & $1: 47$ \\
\hline Female - Without Intercurrence & $1: 49$ \\
\hline Female - With Intercurrence & $1: 52$ \\
\hline Male - Without Intercurrence & $1: 42$ \\
\hline Male - With Intercurrence & $1: 37$ \\
\hline
\end{tabular}

Figura 04 - Mean of general surgical time, separated by genders, with and without intercurrences

\section{Discussion}

The knowledge about the patient's systemic condition through his/her vital signs guarantees security for the dental surgical procedure's performance ${ }^{14}$. Furthermore, the monitoring of these physiological indicators by normal levels and stress situations, allows a most appropriate planning, seeking to avoid emergency situations $^{19}$. It is extremely clinical and scientific relevant the arterial pressure physiology by the dentist ${ }^{14}$. The 55 volunteers of the research did not show comorbidy, decreasing the probability of bias on the arterial pressure and heart rate measurement.

Results found in relation to anxiety in the 55 patients, between 16 men of the sample, 8 reported they were anxious (50\%). However, between the 39 women, 29 reported anxiety $(74,35 \%)$, proving that women are more anxious than men.

This study corroborates with Costa et al (2012) ${ }^{19}$, Oliveira et al (2007) ${ }^{22}$ e Maggirias \& Locker (2002) ${ }^{23}$ results. It was performed a study with 180 adult patients that would be subjected to dental extraction, and applied to the Corah's (DAS de Corah) Dental Anxiety Scale, which consists in 4 multiple choice questions and it is frequently used to measure the dental anxiety level. The work concluded that the distribution of DAS scores in man was relatively bimodal comparing to women. The average of DAS scores was greater in the female gender in relation to male, which was also observed in this research ${ }^{24}$.

In this study it was possible to observe that during the surgical procedure there was no meaningful variation in relation to Heart rate, and all the values were inside the normality limits. This result corroborates with Medeiros et al $(2013)^{20}$, which affirms that there was no meaningful differences $(p>0,05)$ on heart rate 
during the third molar surgical procedures. Costa et al (2012) ${ }^{19}$ in his results also did not find meaningful difference in relation to Heart rate, however, they reported that their sample was insufficient to show more sensible alterations on the vital signs.

Arterial pressure systolic and arterial pressure diastolic of all the research participants evaluated, it was observed a statistically meaningful difference. However, this difference comes to the raise values, in average, of the women, given that on males there was no meaningful difference. It can be concluded that women are more anxious comparing to men. Other studies also affirmed that women are more anxious in relation to men. Other studies also affirmed that women have greater levels of anxiety ${ }^{25}$.

The women show, in average, fear and anxiety scores bigger than men towards dental procedures ${ }^{26,27,}$ 28, 29. On Ferraz et al (2007) ${ }^{14}$ study, 159 individuals of both genders participated, with indication to dental extraction of at least one tooth. It was performed the arterial pressure measurement in four moments: at the waiting room 10 minutes before the surgery (1), preanesthestic (2), during the tooth extraction (3) and 10 minutes after the suture (4). The study evaluates all the 4 moments together and also between 2 moments. When the evaluation between moment 1 and 4 is done, which means, before and after the surgery, the results corroborate with the ones found in the present research. There is a meaningful difference on arterial pressure systolic as much as on arterial pressure diastolic.

The results of this study, in the cases that the complications occurred during the third molars extraction procedure, reveal a meaningful arterial pressure variation. The higher arterial pressure systolic and arterial pressure diastolic values are found on the second measure moment, after the surgical procedure. It suggests that the arterial pressure variations can be attributed to the stress caused by the complication. Among the related complication by the patients are: pain because of the ineffective anesthesia, difficulties in the professional to suture, root fracture, and also dentist's insecurity. Painful, aversive or extremely frightening situations perform an important role in anxiety development to odontological treatment ${ }^{30}$. Given that, it is needed that the dentist performs an atraumatic procedure in order to minimize the tension of his/her client, avoiding vital function alterations ${ }^{14}$.

In relation to the gender in this complication situation, women and men had high arterial pressure systolic levels. However, the arterial pressure diastolic only had an increase in women. Which suggests that in this kind of occurrence, both men and women felt anxious. The arterial pressure systolic increase is characteristic of the sympathetic nervous system activation and of the endogenous catecholamine release. A hypothesis that would justify the greater anxiety level on women are the hormonal alterations. However, it was not evaluated in the present study, in which stage of the menstrual cycle the volunteers were, because the literature confirms that in the pre-menstrual period the pain threshold is reduced, which results in a raise of painful sensation ${ }^{31}$.

In the cases which there were not complications, it was observed a meaningful arterial pressure systolic difference due to the women's values, in average. In the survey of the male gender there was no difference, confirming again the greater anxiety level in women in relation to men. On the other side, the arterial pressure diastolic values do not present statistically meaningful differences, in both men and women.

The surgical time could be related to the raise of anxiety levels. However, the results showed that there was no meaningful difference between the time of the procedures, therefore, in the present work it cannot be affirmed the relation.

\section{Conclusion}

- A heart rate did not show itself as an anxiety physiological indicator in the present study.

- Situations that there were no complications showed meaningful variations only on arterial pressure systolic in females.

- Situations with complications cause arterial pressure systolic variations both in men and women. The arterial pressure diastolic has a meaningful variation only in woman.

- It can be concluded on the studied conditions, that women are more anxious than men.

- Men only show a raise of anxiety in cases that there were complications during the surgical procedure.

- The arterial pressure systolic greater peak moment is on post-surgery.

- There is no correlation between anxiety and the surgery time.

\section{References}

[1]. CM Ferreira, ED Gurgel-Filho, G Bonecker-Valverde, EH Moura, G Deus, T Coutinho-Filho. Ansiedade Odontológica: Nível, prevalência e comportamento. RBPS, 2004; 17(2):51-55.

[2]. K Kanegane. Ansiedade ao tratamento odontológico de urgência e a sua relação com a dor e os níveis de cortisol salivar [Dissertação de Mestrado] São Paulo: Faculdade de Odontologia da USP; 2007.

[3]. DCF Boleta-Ceranto, FJ Bianchi, CSN Miura, MCFA Veiga, LL Bremm. Influence of orofacial pain, in superficial and deep tissue, on the anxiety levels in rats. Rev odonto ciênc. 2010; 25(4):376-381. 
[4]. ED Andrade. Terapêutica medicamentosa em odontologia: procedimentos clínicos e uso de medicamentos nas principais situações da prática odontológica. $1^{\text {a }}$ ed. São Paulo: Artes Médicas; 2000. p.39

[5]. RC Barreto, GAS Pereira. Farmacoterapia na clínica Odontológica. 1a ed. João Pessoa: Editora Universitária (UFPB); 2008.

[6]. C Maniglia-Ferreira, ED Gurgel Filho, GB Valverde, EH Moura, G Deus, T Coutinho Filho. Ansiedade odontológica: nível, prevalência e comportamento. Revista Brasileira em Promoção da Saúde, 2004; 17:51-55.

[7]. L Wannmacher, MBC Ferreira. Farmacologia clínica para dentistas. $3^{\text {a }}$ Ed. Rio de Janeiro: Guanabara Koogan. $2007 ; 403$ p.

[8]. JE Nathan. Behavioral management strategies for young pediatric dental patients with disabilities. Journal of Dentistry for Children. 2001; 68(2):89-101.

[9]. LY Kiyohara, LK Kayano, LM Oliveira, MU Yamamoto, MM Inagaki, NY Ogawa, et al. Surgery information reduces anxiety in the pre-operative period. Rev Hosp Clin Fac Med, 2004; 59(2):51-56.

[10]. AR Silvestri Jr, I Singh. The unresolved problem of the third molar. Would people be better off without it? Journal of the American Dental Association. 2003; 134(4):450-455.

[11]. 11. J Zanatta, MB Hafner, GS Rolim, ABA Moraes. Procedimento preparatório face a face e respostas de ansiedade e dor em exodontia de terceiro molar. Rev Dor, 2012; 13(3).

[12]. JCR Cavalcanti, MV Gayotto, C Costa, JCN Delboni. Estudo comparativo entre as pressões arteriais de pacientes submetidos a cirurgia odontológica. Rev ABO Nac, 1995; 3(1):30-2.

[13]. ALA Bronzo, CG Cardoso Jr , KC Ortega, D Mion Jr. Felipressina aumenta pressão arterial durante procedimento odontológico em pacientes hipertensos. arq bras cardiol, 2012.99(2):724-731.

[14]. EG Ferraz, CM Carvalho, AA Jesuíno, L Provedel, VA Sarmento. Avaliação da variação da pressão arterial durante o procedimento cirúrgico odontológico. Revista de Odontologia da UNESP. 2007; 36(3):223-229.

[15]. ER Bottan, F Pelegrini, JC Stein, MMGA Farias, SM Araujo. Relação entre consulta odontológica e ansiedade ao tratamento odontológico: estudo com um grupo de adolescentes. RSBO. Revista Sul-Brasileira de Odontologia, 5(3):27-32, 2008.

[16]. VZ Pereira, RC Barreto, GAS Pereira, HRBB Cavalcanti. Avaliação dos níveis de ansiedade em pacientes submetidos ao tratamento odontológico. Revista Brasileira de Ciências da Saúde. 17(1): 55-64, 2013.

[17]. MA Ferreira, MC Manso, S Gavinha. Ansiedade e Fobia Dentária-Avaliação psicométrica num estudo transversal. Revista Portuguesa de Estomatologia e Cirurgia Maxilofacial, 2008; 49(2):77-86.

[18]. RF Possobon, KC Carrascoza, ABA Moraes, AL Costa Jr. O tratamento odontológico como gerador de ansiedade. Psicologia em Estudo, 2007; 12(3):609-616.

[19]. RR Costa, PVR Silva, L Iwaky Filho, WM Takeshita, GJ Farah. Avaliação da influência da expectativa e da ansiedade do paciente odontológico submetido a procedimento cirúrgico a partir de seus sinais vitais. Rev Odontol, 2012; 21(1):43-47.

[20]. LA Medeiros, FMS Ramiro, CAA Lima, LMA Souza, TMV Fortes, FC Groppo. Avaliação do grau de ansiedade dos pacientes antes de cirurgias orais menores. Rev Odontol, 2013; 42(5):357-363.

[21]. 21.SOCIEDADE BRASILEIRA DE CARDIOLOGIA / SOCIEDADE BRASILEIRA DEHIPERTENSÃO / SOCIEDADE BRASILEIRA DE NEFROLOGIA. VI Diretrizes Brasileiras de Hipertensão. Arq Bras Cardiol. 2010; 95(1):5.

[22]. 22.PC Oliveira, DZ Barbosa, HJ Souza HJ, JD Batista, J Ranali, MDMA Costa, et al. Avaliação do nível de ansiedade e dor de pacientes em urgências endodônticas e sua influência sobre parâmetros cardiovasculares. Cienc Odontol Bras. 2007; 10:70-5.

[23]. 23.J Maggirias, D Locker. Five-year incidence of dental anxiety in an adult population. Community Dent Health. 2002;19:173-9.

[24]. 24.FL Liau, SH Kok, JJ Lee, RC Kuo, CR Hwang, PJ Yang, et al. Cardiovascular influence of dental anxiety during local anesthesia for tooth extraction. Oral Surg Oral Med Oral Pathol Oral Radiol Endod. 2008; 105(1):16-26.

[25]. 25.O Vassend. Anxiety, pain and discomfort associated with dental treatment. Behav Res Ther. 1993; 31(7):659-666.

[26]. 26.M Hakeberg, C Hagglin, U Berggren, SG Carlsson. Structural relationships of dental anxiety, mood and general anxiety. Acta Odontol Scand. 2001; 59:99 - 103.

[27]. 27.AL Rosa, CM Ferreira. Ansiedade Odontológica: Nível de ansiedade, prevalência e comportamento dos indivíduos ansiosos. Rev Bras Odont. 1997. 54(3):171 - 174

[28]. 28.DSMQ Taani. Dental fear among a young adult Saudian population. Int Dent J. 2001; 51:62-66.

[29]. 29.AA Schuller, T Willunsen, D Holst. Are the differences in oral health and oral health behavior between individuals with high and low dental fear? Commun Dent Oral Epidem. 2003. 31(2):116.

[30]. 30.A De Jongh, IHA Aartman, N Brand. Trauma-related phenomena in anxious dental pacients. Commun Dent Oral Epidem. 2003; 31(1):52.

[31]. 31. MC Cé. Avaliação da dor orofacial por disfunção temporomandibular no ciclo menstrual [dissertação de mestrado] São Paulo; 2008. 